Open Access

\title{
Oligomer-targeting with a conformational antibody fragment promotes toxicity in $A \beta$-expressing flies
}

\author{
Jessica Wacker ${ }^{1,9}$, Raik Rönicke ${ }^{2}$, Martin Westermann ${ }^{3}$, Melanie Wulff ${ }^{1,4}$, Klaus G Reymann ${ }^{2}$, Christopher M Dobson
} Uwe Horn $^{6}$, Damian C Crowther ${ }^{7,8}$, Leila M Luheshi ${ }^{5}$ and Marcus Fändrich ${ }^{1,4^{*}}$

\begin{abstract}
Introduction: The self-assembly of $A \beta$ peptides into a range of conformationally heterogeneous amyloid states represents a fundamental event in Alzheimer's disease. Within these structures oligomeric intermediates are considered to be particularly pathogenic. To test this hypothesis we have used a conformational targeting approach where particular conformational states, such as oligomers or fibrils, are recognized in vivo by state-specific antibody fragments.

Results: We show that oligomer targeting with the KW1 antibody fragment, but not fibril targeting with the B10 antibody fragment, affects toxicity in A $\beta$-expressing Drosophila melanogaster. The effect of KW1 is observed to occur selectively with flies expressing $A \beta(1-40)$ and not with those expressing $A \beta(1-42)$ or the arctic variant of $A \beta(1-42)$ This finding is consistent with the binding preference of $\mathrm{KW} 1$ for $A \beta(1-40)$ oligomers that has been established in vitro. Strikingly, and in contrast to the previously demonstrated in vitro ability of this antibody fragment to block oligomeric toxicity in long-term potentiation measurements, KW1 promotes toxicity in the flies rather than preventing it. This result shows the crucial importance of the environment in determining the influence of antibody binding on the nature and consequences of the protein misfolding and aggregation.
\end{abstract}

Conclusions: While our data support to the pathological relevance of oligomers, they highlight the issues to be addressed when developing inhibitory strategies that aim to neutralize these states by means of antagonistic binding agents.

Keywords: Conformational disease, Misfolding, Neurodegeneration, Prion, Protein aggregation

\section{Introduction}

Amyloid fibrils are filamentous polypeptide aggregates characterizing a range of human diseases, including systemic amyloidosis and a variety of neurodegenerative conditions [1-4]. In Alzheimer's disease they are formed from $\beta$-amyloid $(A \beta)$ peptide [5-8]. This peptide is able to aggregate into a multitude of different assembly states [2-4]. It also occurs in different chemical isoforms [9-11], but oligomeric intermediates of fibril formation are often reported to play a pivotal role in $\mathrm{AD}$ pathogenesis $[6-8,12,13]$. Much of the evidence supporting this view has come from in vitro toxicity measurements or structures

\footnotetext{
*Correspondence: marcus.faendrich@uni-ulm.de

'Max-Planck Research Unit for Enzymology of Protein Folding, 06120 Halle, Saale, Germany

${ }^{4}$ Institute for Pharmaceutical Biotechnology, Ulm University, Helmholtzstr. 8/1, 89081 Ulm, Germany

Full list of author information is available at the end of the article
}

that were prepared inside the test tube or extracted from its native sources by highly invasive biochemical methods $[6,8,12,14-16]$. Oligomers have thus been suggested as targets of therapeutic or inhibitory strategies ameliorating $\mathrm{AD}$, and oligomer binding ligands, including conformational antibodies, were shown to antagonize their antineuronal activity in various assay systems [17-21].

To probe for the presence and relevance of specific $A \beta$ states in vivo, we have carried out a conformational targeting study, introducing two biophysically well-characterised conformation-specific $A \beta$ antibody fragments into a Drosophila model of $A \beta$ toxicity. Fly models are well defined model systems and gave important insights into the toxicity of $A \beta$ and other polypeptide chains [22-28]. For our study we used flies expressing the 40 and 42 amino acid isoforms $A \beta(1-40)$ and $A \beta(1-42)$ and the disease-associated E22G mutant of $A \beta(1-42)$, termed 
$\mathrm{A} \beta(1-42)$ arc [10] as well as two antibody fragments that were generated previously through a biotechnological approach. That is, they were phage display selected based on their ability to discriminate between different conformational states of $\mathrm{A} \beta$ from a fully synthetic library of camelid heavy chain antibody fragments [17,29].

These monoclonal antibody fragments introduced into the flies are termed KW1 and B10 (Figure 1A,B) [29,30]. KW1 binds oligomers of $A \beta(1-40)$, while fibrils and disaggregated, that is largely monomeric, $A \beta(1-40)$ peptide, or oligomers of the more aggregation-prone $A \beta(1-42)$ peptide are not specifically recognized [14]. Bivalent KW1 binds to $A \beta(1-40)$ oligomers with an apparent dissociation constant $\left(\mathrm{aK}_{\mathrm{D}}\right)$ of $43.5 \mathrm{nM}$ and antagonizes oligomer toxicity in long term potentiation (LTP) electrophysiology experiments [14]. B10, by contrast, recognizes $A \beta(1-40)$ fibrils $(\mathrm{aK}=7 \mathrm{nM}$, determined for bivalent $\mathrm{B} 10)$, but no oligomers or disaggregated peptide [31,32]. B10 is less selective than KW1 and binds fibrils formed from a broad range of polypeptide chains, including those of $A \beta(1-40)$ and $\mathrm{A} \beta(1-42)$ [30-34].

These properties, combined with the ability to promote the formation of either protofibrillar (B10) or non-fibrillar aggregates (KW1) of $\mathrm{A} \beta[29,30,35]$, and to bind to their corresponding conformers in human tissue samples [29,30,32], enable B10 and KW1 to be used to probe in a precise and well-defined manner how the binding of particular $\mathrm{A} \beta$ conformers in a Drosophila model of $A \beta$ toxicity affects its self-assembly and consequent neurodegeneration in vivo. By correlating these observations with parallel studies of the effects of these antibody fragments on the formation of cytotoxic aggregates in vitro, we are able to rationalise their ability (or lack of ability) to modulate the neurotoxicity of each $\mathrm{A} \beta$ isoform in vivo on the basis of their conformational selectivity.

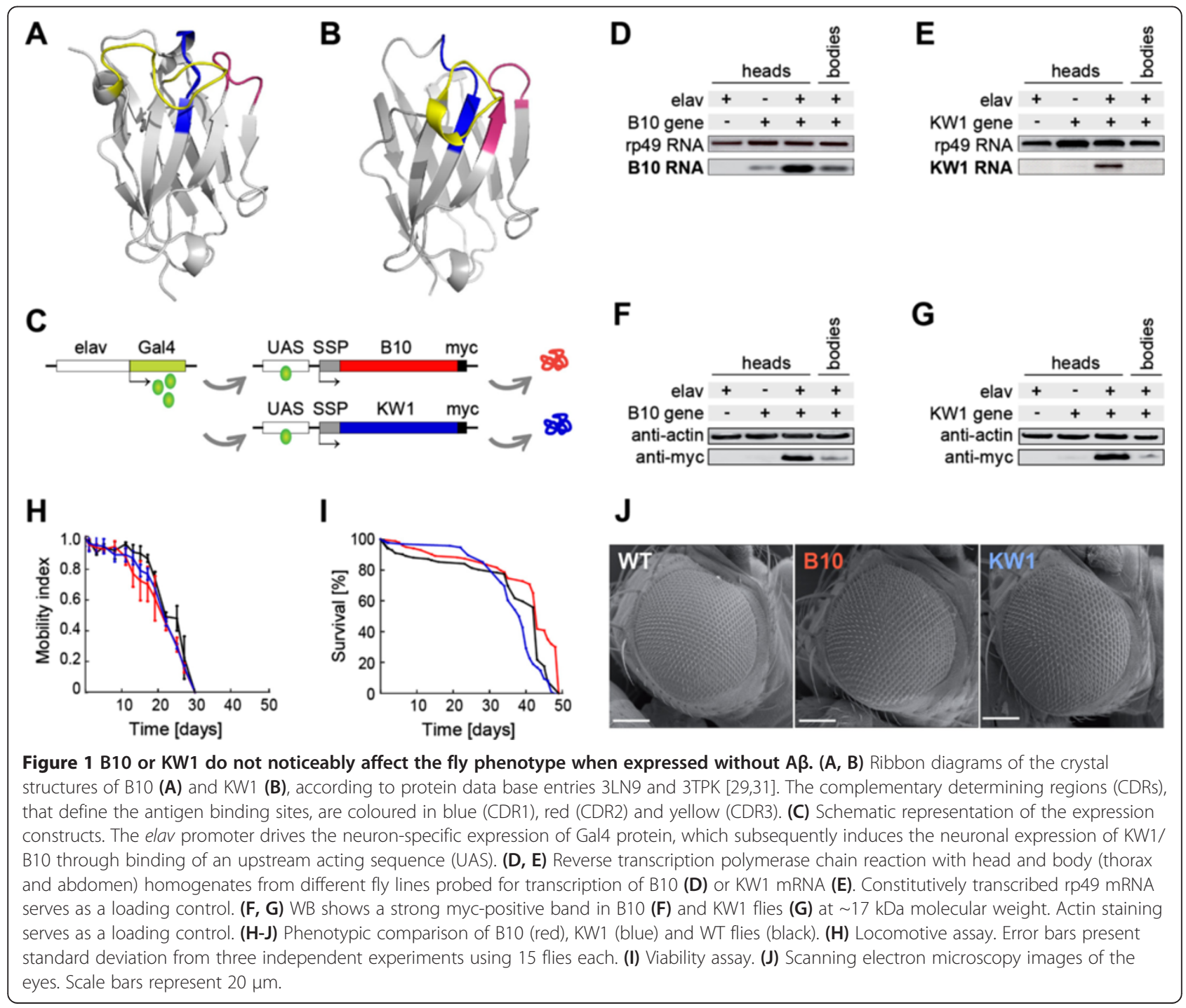




\section{Materials and methods Preparation of different $A \beta$ conformers}

The $A \beta(1-40)$ peptide was recombinantly expressed in house [36], while the $A \beta(1-42)$ and $A \beta(1-42)$ arc peptides were obtained from chemical synthesis (Dr. Sven Rothemund, University Leipzig, Germany). The purity was $>96 \%$, based on reverse phase high performance liquid chromatography. Fibrils were formed in vitro by incubation of pure peptide at $1 \mathrm{mg} / \mathrm{ml}$ concentration in $50 \mathrm{mM}$ sodium borate buffer, $\mathrm{pH}$ 9.0, for 5 days at room temperature. Oligomers were prepared by dissolving pure peptide at $2.5 \mathrm{mg} / \mathrm{ml}$ concentration in 100\% 1,1,1,3,3,3hexafluoro-2-propanol [37]. After incubation for $15 \mathrm{~min}$ at room temperature, the solution was diluted 10 -fold with $\mathrm{H}_{2} \mathrm{O}$ and further incubated for $15 \mathrm{~min}$. Large aggregates were then removed by spinning down the sample at $14,000 \times g$ for $15 \mathrm{~min}$. The supernatant containing the oligomers was used for further analysis.

\section{Generation of B10 or KW1 transgenic flies}

The coding sequences for KW1 and B10 were obtained by chemical synthesis (GeneArt), codon optimized for Drosophila melanogaster. The genes were cloned into the Gal4-responsive pUAST/attB expression vector (kind gift of Konrad Basler; [38] and flanked by a $5^{\prime}$-SSP sequence from Drosophila necrotic gene [39] and a 3'myc-tag (Additional file 1: Figure S1A). B10 and KW1 transgenic flies were commercially generated by PhiC31 integrase-mediated transgenesis using the attP landing line zh-51D (Best Gene Inc.). Through polymerase chain reaction of the genomic DNA from the two initial fly lines $+/+$;B10/CyO;+/+and $+/+; \mathrm{KW} 1 / \mathrm{CyO} ;+/+$ we confirmed the presence of the KW1/B10 constructs within the genomic DNA. B10 or KW1-expressing flies were obtained through further crossing of these flies with the Gal4-elav ${ }^{\mathrm{c} 155}$ pan-neuronal driver strain (Bloomington). The Gal4-UAS system involves an upstream activating sequence (UAS) element that activates the transcription of KW1 or B10 when bound by Gal4 protein [40]. Gal4 expression, in turn, is controlled by the pan-neuronal elav $^{c 155}$ promoter, which induces a neuron-specific expression pattern of Gal4 protein along with KW1 or B10. The resulting strains are referred to in the text as B10 or KW1 flies.

To co-express $B 10$ or KW1 with $A \beta$, we crossed the commercially obtained $+/+; \mathrm{B} 10 / \mathrm{CyO}+/+$ and $+/+; \mathrm{KW} 1 /$ $\mathrm{CyO} ;+/+$ lines with flies transgenic for $\mathrm{A} \beta(1-40), \mathrm{A} \beta(1-42)$ or $A \beta(1-42)$ arc that had not previously been crossed with the Gal4-elav ${ }^{\mathrm{c} 155}$ driver strain. This initial cross resulted in the three initial $B 10$ and $A \beta$ double-transgenic strains $+/+$; B10/CyO;A $\beta(1-40) / T M 6 B,+/+; B 10 / C y O ; A \beta(1-42) / T M 6 B$ and $+/+; \mathrm{B} 10 / \mathrm{CyO} ; \mathrm{A} \beta(1-42) \operatorname{arc} / \mathrm{TM} 6 \mathrm{~B}$ as well as the three KW1 and $A \beta$ double-transgenic strains $+/+; \mathrm{KW} 1 /$ CyO;A $\beta(1-40) / \mathrm{TM} 6 \mathrm{~B}, \quad+/+; \mathrm{KW} 1 / \mathrm{CyO} ; \mathrm{A} \beta(1-42) / \mathrm{TM} 6 \mathrm{~B}$ and $+/+; \mathrm{KW} 1 / \mathrm{CyO} ; \mathrm{A} \beta(1-42) \operatorname{arc} / \mathrm{TM} 6 \mathrm{~B}$. Through a second cross of these flies with the Gal4-elav ${ }^{\mathrm{c} 155}$ strain, we induced the expression of the transgenic proteins. The resulting fly lines are referred to within the main text as $\mathrm{B} 10 ; \mathrm{A} \beta 40, \mathrm{~B} 10 ; \mathrm{A} \beta 42, \mathrm{~B} 10 ; \mathrm{A} \beta 42$ arc, $\mathrm{KW} 1 ; \mathrm{A} \beta 40$, KW1;A 342 and KW1;A $\beta 42$ arc flies. They neuronally express the gal4 gene, which encodes the yeast transcription activator Gal4. Gal4 protein binds to the UAS element, which activates the neuron-specific transcription of $A \beta, K W 1$ or B10.

In addition, we generated two further fly lines that were co-expressing $A \beta(1-40)$ and $K W 1$. These lines were obtained by crossing +/+;KW1/CyO;+/+flies with the Gal4elav $^{\text {c155 }}$ strain to obtain elav/elav;KW1/CyO;+/+flies. The resulting animals were then crossed with the $A \beta(1-40)$ peptide expressing lines $A \beta(1-40)-29.1$, which behaves identically to $A \beta 40$ flies [22], and $A \beta(1-40)-51 D$ [41] flies to generate the lines KW1;A $\beta 40-29.1$ and KW1;A $\beta 40-$ 51D. The respective control lines (no KW1 expression) were obtained by crossing $A \beta(1-40)-29.1$ and $A \beta(1-40)$ 51D flies with the Gal4-elav ${ }^{\text {c155 }}$ strain to generate the $A \beta(1-40)$ expressing lines $A \beta 40-29.1$ and $A \beta 40-51 D$. All crosses were carried out at $25^{\circ} \mathrm{C}$ on standard Drosophila food with dried yeast [42].

\section{Survival assay}

Ten groups of ten flies, were incubated at $29^{\circ} \mathrm{C}$ in 4 -inch glass vials (100 flies in total). The animals were kept on standard food with dried yeast, and the food was replenished every 2 days. The number of living flies was counted every 2-3 days, and the resulting survival curves were evaluated with the Kaplan-Meier method that is implemented within the Sigma Plot11 software (Systat Software Inc). Differences between the genotypes were assessed by using the log-rank test (Sigma Plot11). All survival times quoted in the text and in Table 1 represent median values \pm standard error of mean.

\section{Negative geotaxis assay}

A negative-geotaxis assay was used to determine the locomotor ability of the flies. A total of 15 flies $\left(n_{\text {total }}\right)$

\section{Table 1 Median survival time of the fly lines}

\begin{tabular}{|c|c|c|c|}
\hline \multirow[t]{2}{*}{ Expressed $A \beta$ variant } & \multicolumn{3}{|c|}{ Expressed antibody fragment } \\
\hline & None & B10 & KW1 \\
\hline None & $43 \pm 0.1$ & $43 \pm 0.2$ & $42 \pm 1.1$ \\
\hline$A \beta(1-42) \operatorname{arc}$ & $7 \pm 0.1$ & $6 \pm 0.3$ & $7 \pm 0.2$ \\
\hline$A \beta(1-42)$ & $32 \pm 0.3$ & $31 \pm 0.6$ & $32 \pm 0.3$ \\
\hline$A \beta(1-40)$ (line $A \beta 40)$ & $43 \pm 0.6$ & $41 \pm 0.9$ & $28 \pm 1.1$ \\
\hline$A \beta(1-40)$ (line $A \beta 40-51 D)$ & $42 \pm 1.1$ & - & $36 \pm 0.8$ \\
\hline$A \beta(1-40)$ (line $A \beta 40-29.1)$ & $39 \pm 0.8$ & - & $39 \pm 0.4$ \\
\hline
\end{tabular}

Values are given in days. Original data are shown in Figures 1 and 2 and Additional file 1: Figure S4. Errors represent standard error of mean. 
were placed in a $25 \mathrm{ml}$ plastic pipette and knocked to the bottom. After 45 seconds, the number of flies that had reaching the top of the pipette $\left(n_{\text {top }}\right)$, as defined by the $25 \mathrm{ml}$-mark, was determined. The number of flies remaining at the bottom ( $n_{\text {bottom }}$ ) was defined by the 2 ml-mark. From these numbers the mobility index was calculated according to the equation $\left(n_{\text {total }}+n_{\text {top }}-n_{\text {bot- }}\right.$ tom $) / 2 \cdot n_{\text {total }}$. This measurement was repeated three times with independent groups of flies, consisting of 15 animals each. Climbing index values quoted in the text represent mean values from the three independent measurements \pm standard error of mean.

\section{Scanning electron microscopy analysis of the eye morphology}

Ten 1-day old adult animals were collected from each analyzed fly line, anesthetized with carbon dioxide and fixed over night in $500 \mu \mathrm{l}$ of a $100 \mathrm{mM}$ sodium cacodylate solution $(\mathrm{pH} 7.3)$ containing $2.5 \%$ glutaraldehyde $\left(4^{\circ} \mathrm{C}\right)$. The fixative was removed by washing the flies 5 times for $5 \mathrm{~min}$ in $500 \mu \mathrm{l}$ sodium cacodylate buffer without glutaraldehyde, followed by a series of 5 dehydration steps $(500 \mu \mathrm{l}$ each), where the ethanol concentration was progressively raised from 10 to $100 \%$. The organic solvent was removed by critical point drying in a BAL-TEC CPD 030 Critical Point Dryer. All samples were evacuated and sputtered with gold (layer thickness $20 \mathrm{~nm}$ ) in a BAL-TEC SCD 005 Sputter Coater. The final analysis was done using a scanning electron microscope Zeiss (LEO) $1450 \mathrm{VP}$ at $8 \mathrm{kV}$ acceleration voltage and pictures were taken at $200 \times$ magnification.

\section{Immunohistochemistry}

Whole brains were dissected from adult fly heads and transferred into $500 \mu \mathrm{l}$ ice cold PBS. For fixation the brains were then transferred into $4 \%(\mathrm{w} / \mathrm{v})$ paraformaldehyde in PBS for $1 \mathrm{~h}$ at room temperature. Afterwards the fixative was removed and the brains were blocked with $5 \%$ normal goat serum in PBS (15 min). The brains were then infiltrated for $2 \mathrm{~h}$ with $6 \mathrm{E} 10$ (A $\beta 1-16$, monoclonal, mouse, Covance, 1:500), anti-elav (monoclonal, rat, DHSB, 1:50) or anti-myc antibody (ab9106, polyclonal, rabbit, Abcam, 1:500). All antibodies were diluted in PBT (PBS $+0.05 \%$ TritonX-100). Unbound antibodies were removed with three washing steps $(500 \mu \mathrm{l}$ PBT, $10 \mathrm{~min}$ each) followed by a $1 \mathrm{~h}$ incubation with donkey anti-mouse IgG Alexa Fluor ${ }^{\circ} 555$, donkey anti-rabbit IgG Alexa Fluor 488 (Molecular Probes, 1:200) or anti-rat IgG TRITC (JacksonImmuno Research, 1:200) as appropriate. To remove unbound secondary antibodies, the brains were washed three times with $500 \mu \mathrm{l} \mathrm{PBT}$, before they were incubated $10 \mathrm{~min}$ with $500 \mu \mathrm{l}$ Hoechst 33342 dye $(1 \mu \mathrm{g} / \mathrm{ml}$ in $\mathrm{PBS})$ to stain the nuclei. Finally, the brains were mounted using VECTASHIELD ${ }^{\circ}$ mounting medium (Vector laboratory). All steps were performed at room temperature, unless indicated otherwise. All samples were analysed using a Nikon ECLIPSE TE2000-E confocal laser-scanning microscope. Pictures were taken at a magnification of $60 \times$.

\section{Protein extraction from flies}

Flies were anesthetized, shock frozen on dry ice and decapitated. Depending on whether the proteins samples were supposed to be used for denaturing sodium dodecylsulphate (SDS) polyacrylamide gel electrophoresis (PAGE) or native PAGE we then used slightly different extraction methods. Denaturing SDS PAGE analysis: we homogenized $20 \mathrm{fly}$ heads or $5 \mathrm{fly}$ bodies in $20 \mu \mathrm{l}$ phosphate-buffered saline (PBS, $137 \mathrm{mM} \mathrm{NaCl} ; 2.7 \mathrm{mM}$ $\mathrm{KCl} ; 8 \mathrm{mM} \mathrm{Na}_{2} \mathrm{HPO}_{4} ; 2 \mathrm{mM} \mathrm{KH_{2 }} \mathrm{PO}_{4} ; \mathrm{pH}$ 7.4), which was supplemented with $1 \%$ SDS and the complete protease inhibitor cocktail (Roche Applied Science). Homogenization was performed manually by using a plastic pistil. The homogenates were sonicated for $8 \mathrm{~min}$ and spun down for $7 \mathrm{sec}$, before the supernatants were collected. The protein concentrations in these samples were determined with the DC Protein Assay (Biorad), and the protein concentration was adjusted in the various samples to ensure equal loading on the gel. All samples were then mixed with $5 \mu \mathrm{l} 4 \times$ NuPAGE $^{\oplus}$ sample buffer (Invitrogen) and heated for $10 \mathrm{~min}$ at $95^{\circ} \mathrm{C}$. The samples were then separated on NuPAGE $^{\oplus}$ 4-12\% Bis-Tris gradient gels with NuPAGE ${ }^{\oplus}$ MES SDS running buffer (Invitrogen).

For native PAGE analysis, we manually homogenized 20 fly heads in $20 \mu \mathrm{l}$ PBS, supplemented with the cOmplete protease inhibitor mix. This suspension was sonicated for $8 \mathrm{~min}$, spun down for $7 \mathrm{sec}$ to remove insoluble material, and the supernatant was mixed with 5 $\mu \mathrm{l}$ of $4 \times$ NativePAGE $^{\circledast}$ sample buffer (Invitrogen). These electrophoresis samples were not boiled before they were separated on NativePAGE ${ }^{\oplus}$ 4-16\% Bis-Tris gradient gels with NativePAGE ${ }^{\oplus}$ running buffer (Invitrogen). The further readout of the results was performed with WB analysis, if required.

\section{RNA extraction and polymerase chain reaction}

To check the transcription of the KW1 and B10 genes in the animals, we used a three step protocol: RNA extraction from the flies, conversion of RNA into cDNA and analysis of the cDNA to confirm the coding sequences of B10 or KW1.

RNA isolation was based on TRIzol $^{\circledR}$ reagent (Invitrogen). In brief, flies were anesthetized and shock frozen on dry ice in Eppendorf tubes. Flies were decapitated by shaking the Eppendorf tube on dry ice to break the neck of the flies. The heads were manually separated from the remaining bodies. 15-20 heads or 5 bodies were homogenized in $150 \mu \mathrm{l} \mathrm{TRIzol}{ }^{\circ}$ by using a plastic pistil. 
After addition of $30 \mu \mathrm{l}$ chloroform, the mixture was thoroughly vortexed and the organic and aqueous phases were separated by centrifugation $(13,000 \times g$, $15 \mathrm{~min}, 4^{\circ} \mathrm{C}$ ). The aqueous phase was transferred into a new tube and all nucleic acids were precipitated by using $75 \mu \mathrm{l}$ pure isopropanol, followed by centrifugation at $13,000 \times g$ for $15 \mathrm{~min}$ at $4^{\circ} \mathrm{C}$. The pellet was briefly washed with $150 \mu \mathrm{l}$ of $70 \%$ ethanol, air dried and re-dissolved in $20 \mu \mathrm{l}$ RNAse free water.

As a next step, $1 \mu \mathrm{g}$ of the purified RNA was transferred into a fresh tube and the residual genomic DNA was removed by enzymatic digestion with 1 unit DNAse for $30 \mathrm{~min}$ at room temperature. All of the resulting pure RNA was then used for reverse transcription polymerase chain reaction to generate cDNA (RevertAid ${ }^{\mathrm{mm}}$ First Strand cDNA Synthesis Kit, Fermentas), which was used according to the manufacturer's instructions.

Finally, $1 \mu \mathrm{l}$ of the resulting cDNA were subjected to polymerase chain reaction, which consisted of an initial denaturation step [ $5 \mathrm{~min}$ at $95^{\circ} \mathrm{C}$ ] followed by 28 cycles each of which consisted of $30 \mathrm{sec}$ at $95^{\circ} \mathrm{C}$ [denaturation], $30 \mathrm{sec}$ at $57^{\circ} \mathrm{C}$ [primer annealing] and $30 \mathrm{sec}$ at $72^{\circ} \mathrm{C}$ [elongation]. At the end of these cycles we applied a final extension step of $5 \mathrm{~min}$ at $72^{\circ} \mathrm{C}$. The polymerase chain reaction products were separated on an agarose gel and photographically imaged. Primers used to amplify B10 and KW1 cDNA were designed based on the coding sequences of KW1 and B10 genes. Primers used to amplify $\mathrm{A} \beta \mathrm{CDNA}$ were designed based on the coding sequences of $\mathrm{A} \beta$ transgene. Amplified rp49 cDNA served as a loading control. See Additional file 1: Table S1 for primers.

\section{Immunoprecipitation}

Magnetic protein A coupled beads (Invitrogen) were pretreated by blocking $10 \mu \mathrm{l}$ of the resuspended beads in $100 \mu \mathrm{l} 2 \% \mathrm{BSA}$ in PBS $+0.025 \%$ TritonX-100. After incubation for $15 \mathrm{~min}$, the beads were washed twice in $100 \mu \mathrm{l}$ PBS $+0.025 \%$ TritonX-100 for $5 \mathrm{~min} .3 \mu \mathrm{g}$ of the dissolved antibody (6E10) were added to $100 \mu \mathrm{l}$ PBS $+0.025 \%$ TritonX-100 and incubated with the beads for 15 min to allow coupling of the antibodies to the beads. After this pre-treatment, 10 to 20 fly heads were homogenized with a plastic pistil in $20 \mu \mathrm{l}$ PBST containing the cOmplete protease inhibitor mix. The suspension was sonicated for $1 \mathrm{~min}$, centrifuged for $7 \mathrm{sec}$ and the supernatant was transferred into a fresh tube. This solution was then diluted with $80 \mu \mathrm{l}$ PBS $+0.025 \%$ TritonX-100, mixed with the pre- treated beads and incubated for $20 \mathrm{~min}$. The beads were washed thrice with $100 \mu \mathrm{l}$ PBS $+0.025 \%$ TritonX-100 (5 min) and transferred into a fresh tube. Specifically bound proteins were eluted from the beads with $20 \mu \mathrm{l} 50 \mathrm{mM}$ glycine $(\mathrm{pH} 2.8)$ and incubation for $10 \mathrm{~min}$. Afterwards the beads were boiled in $20 \mu \mathrm{l} 1 \times$
NuPAGE ${ }^{\circ}$ LDS Sample Buffer (Invitrogen) and applied onto the gel to check for unspecifically bound proteins. All steps were performed at room temperature, unless indicated otherwise. The resulting fractions were analysed using WB. Anti-myc antibody was used to detect the expressed myc-tagged B10 antibody fragment, while 6E10 was used against $A \beta$.

To test for possible interactions between KW1 and $A \beta$ peptide, a modified protocol had to be used, because fly KW1 (unlike fly B10) was found to directly bind to protein A beads. Therefore, the bead pre-treatment consisted only of the blocking of $10 \mu \mathrm{l}$ resuspended beads (in $100 \mu \mathrm{l} \mathrm{2 \%}$ BSA, PBS, $0.025 \%$ TritonX-100), incubation for $15 \mathrm{~min}$ and two washing steps as described above. After this pre-treatment, 10 to $20 \mathrm{fly}$ heads were prepared as described above and mixed with the pre-treated beads. The further steps were carried out as described above. Anti-myc antibody was used to detect the expressed myc-tagged KW1 antibody fragment via $\mathrm{WB}$, while $6 \mathrm{E} 10$ was used against $\mathrm{A} \beta$. All steps were carried out at room temperature.

\section{Fluorescence spectroscopy}

Thioflavin T (ThT) and 8-naphthalene-1-sulfonate (ANS) spectra were recorded at room temperature using the LS 55 fluorescence spectrometer (Perkin Elmer). All spectra represent averages of 5 scans. ThT fluorescence was excited at $450 \mathrm{~nm}$ and the emission spectrum was recorded between 460 and $700 \mathrm{~nm}$. All ThT spectra were recorded with samples containing $15 \mu \mathrm{M}$ ThT and $20 \mu \mathrm{M}$ A $\beta$. ANS emission spectra were measured from 380 to $700 \mathrm{~nm}$, whilst exciting at $374 \mathrm{~nm}$. In this measurement samples contained $200 \mathrm{mM}$ ANS and $20 \mu \mathrm{M} \mathrm{A} \beta$ peptide.

\section{Spot blot}

1-20 $\mu \mathrm{g}$ from each $\mathrm{A} \beta$ peptide species were blotted onto nitrocellulose membrane (GE Healthcare or Schleicher and Schuell) using pore sizes of $0.1 \mu \mathrm{m}$ or $0.45 \mu \mathrm{m}$. The membrane was blocked for $1 \mathrm{~h}$ with $2 \%$ bovine serum albumin (BSA) solution in TBST, which is Tris- buffered saline (50 mM Tris, $200 \mathrm{mM} \mathrm{NaCl}, \mathrm{pH}$ 7.4), containing $0.01 \%$ Tween 20 . Equal loading was confirmed with Ponceau red staining of unblocked control membranes. Membranes were washed thrice in TBST for $5 \mathrm{~min}$, before they were further incubated for $1 \mathrm{~h}$ with $4 \mu \mathrm{g} / \mathrm{ml}$ B10AP or KW1AP in TBST. B10AP or KW1AP binding was visualized with NBT/BCIP reagent (Pierce). All steps were carried out at room temperature. Densitometric quantifications of the scanned blots were carried out with TotalLab 100 software.

\section{Congo red (CR) absorption spectroscopy}

$\mathrm{CR}$ absorption was measured at room temperature using the Lambda 900 spectrometer (Perkin Elmer). The 
samples contained $15 \mu \mathrm{M} C R$ with or without $25 \mu \mathrm{M} \mathrm{A} \beta$ peptide. Absorbance spectra were recorded from 400 to $700 \mathrm{~nm}$ with 3 scans per spectrum. CR absorption spectra of $\mathrm{A} \beta$ fibrils or buffer control always contained $50 \mathrm{mM}$ sodium borate buffer, $\mathrm{pH}$ 9.0, while $\mathrm{A} \beta$ oligomers or controls were measured in 10\% 1,1,1,3,3,3-hexafluoro-2propanol (HFIP).

\section{Aggregation kinetics measurements}

Aggregation kinetic measurments are based on timeresolved ThT fluorescence measurements, carried out online in a 96-well plate and by using a FLUOstar OPTIMA (BMG Labtech) plate reader $\left(37^{\circ} \mathrm{C}\right)$. ThT fluorescence was recorded by using excitation and emission wavelengths of $482 \mathrm{~nm}$ and $490 \mathrm{~nm}$, respectively. Each measurement cycle consisted of $30 \mathrm{~min}$ incubation followed by orbital shaking at $100 \mathrm{rpm}$ for 10 seconds immediately before the measurement. Samples were prepared by initially disaggregating $A \beta(1-40)$ peptide as described [43]. The disaggregated peptide was dissolved at high concentration in 100\% dimethyl sulphoxide (DMSO), and the accurate $A \beta$ concentration was determined by absorbance spectroscopy [44]. To that end we diluted $10 \mu \mathrm{l}$ of the DMSO-stock with $190 \mu \mathrm{l}$ pure water and $800 \mu \mathrm{l}$ of $7.5 \mathrm{M}$ guanidine hydrochloride, $25 \mathrm{mM}$ sodium phosphate buffer, $\mathrm{pH}$ 6.5. The optical density at $280 \mathrm{~nm}$ was recorded with a Helios $\gamma$ UV-vis spectrophotometer, and the concentration was derived based on a theoretic molar extinction coefficient of $1280 \mathrm{M}^{-1} \mathrm{~cm}^{-1}$. From the DMSO stock aliquots were diluted with buffer and other reagents to yield the final sample. These samples contained always a volume of $100 \mu \mathrm{l}, 25 \mu \mathrm{M}$ A $\beta(1-40), 20 \mu \mathrm{M}$ ThT, $50 \mathrm{mM}$ HEPES buffer (pH 7.4), $50 \mathrm{mM} \mathrm{NaCl}$, a protease inhibitor cocktail (Complete mini, Roche) (1x) and, where appropriate, $5 \mu \mathrm{M}$ KW1. The DMSO concentration was always less than $5 \%$.

\section{Transmission electron microscopy (TEM)}

TEM specimens of $A \beta$ oligomers and fibrils were prepared by placing $5 \mu \mathrm{l}$ of each sample solution onto a Formvar/carbon copper grid (200 mesh, Plano) followed by $1 \mathrm{~min}$ of incubation. The grid was washed by dipping it subsequently into 3 droplets of water $(\sim 50 \mu \mathrm{l})$ and the specimen were counterstained with 3 droplets $(\sim 50 \mu \mathrm{l})$ of $2 \%(\mathrm{wt} / \mathrm{vol})$ uranyl acetate. Samples were examined using a Zeiss 900 electron microscope that was operated at an acceleration voltage of $80 \mathrm{kV}$. Samples were imaged at a magnification of $30,000 \times$.

\section{Long term potentiation (LTP) measurements}

For measuring the influence of various $A \beta$ species on LTP isolated hippocampal slices (400 $\mu \mathrm{m}$ thickness) were prepared from 4-months old C57/B16 mice as described previously [45]. The slices were maintained in a pre- chamber containing $8 \mathrm{ml}$ carbogen-gasified artificial cerebrospinal fluid (ACSF, $124 \mathrm{mM} \mathrm{NaCl}, 25.6 \mathrm{mM}$ $\mathrm{NaHCO}_{3}, 1.2 \mathrm{mM} \mathrm{KH} \mathrm{PO}_{4}, 4.9 \mathrm{mM} \mathrm{KCl}, 2.5 \mathrm{mM} \mathrm{CaCl}_{2}$, $2 \mathrm{mM} \mathrm{MgSO}_{4}, 10 \mathrm{mM}$ glucose).

We prepared three different $A \beta$-containing samples by incubation of $100 \mu \mathrm{M} A \beta$ with or without $20 \mu \mathrm{M}$ KW1 in $50 \mathrm{mM}$ HEPES buffer (pH 7.4) and $50 \mathrm{mM} \mathrm{NaCl}$ for 5 days at $37^{\circ} \mathrm{C}$ without shaking. The sample incubated without KW1 was divided into two parts. One was applied to the slice as it was, to the other one we added KW1 15 min before addition to the slices. Sample solutions containing $1 \mu \mathrm{M} \mathrm{A} \beta$ were applied to the slices in the pre-chamber for 2 hours. The respective control solution contained no A $\beta$. The slices were then transferred into a submerge-type recording chamber and were allowed to recover for at least $30 \mathrm{~min}$ before starting the electrophysiological experiments. The recording chamber was constantly perfused with ACFS at a rate of $2.5 \mathrm{ml} / \mathrm{min}$ at $32 \pm 1^{\circ} \mathrm{C}$.

Synaptic responses were elicited by stimulation of the Schaffer collateral commission fibers in the stratum radiatum (CA1 region) using lacquer-coated stainless steel stimulating electrodes. Glass electrodes (filled with ACSF, 1-4 M $\Omega$ ) were placed in the apical dendritic layer to record fEPSPs. The initial slope of the fEPSP was used as a measure of this potential. The stimulus strength of the test pulses was adjusted to $30 \%$ of the EPSP maximum. During baseline recording, single stimuli were applied every minute $(0.0166 \mathrm{~Hz})$ and were averaged every 5 min. Once a stable baseline had been established, long-term potentiation was induced by applying 100 pulses at an interval of $10 \mathrm{~ms}$ and a width of the single pulses of $0.2 \mathrm{~ms}$ (strong tetanus) three times at $10 \mathrm{~min}$ intervals.

\section{Protein structure representation}

KW1 and B10 crystal structures were displayed as ribbon diagrams by using the program PyMOL (DeLano Scientific). The structures have the following protein database identification numbers: 3LN9 (B10) and 3TPK (KW1) $[29,31]$.

\section{Recombinant expression of B10AP and KW1AP in E.coli} B10AP and KW1AP were recombinantly expressed in E. coli and purified according to established procedures $[29,30]$.

\section{Cultivation of SH-SY5Y and measurements of metabolic/ toxic activity}

SH-SY5Y cells were grown in Dulbecco's Modified Eagle Medium (DMEM, PAA Laboratories) supplemented with $10 \%$ heat-inactivated fetal bovine serum and 2\% Pen/ Strep (PAA Laboratories) at $37^{\circ} \mathrm{C}$ with $10 \% \mathrm{CO}_{2}$. Cells were seeded into 96-well plates at a density of 50000 
cells/well in $100 \mu \mathrm{l}$ cell culture medium and grown at $37^{\circ} \mathrm{C}$. After $24 \mathrm{~h}$ the medium was removed and fresh medium was added together with the $A \beta$ samples or controls to be analyzed.

The $A \beta$ samples were obtained by initially dissolving disaggregated $A \beta$ at high concentration in 100\% DMSO. The peptide was then quantified and diluted to a final concentration of $100 \mu \mathrm{M}$ into $50 \mathrm{mM}$ HEPES buffer $\mathrm{pH}$ 7.4, containing $50 \mathrm{mM} \mathrm{NaCl}$. If applicable, the solution also contained $20 \mu \mathrm{M}$ B10 or KW1, and it was incubated for different periods of time at $37^{\circ} \mathrm{C}$. After incubation the $A \beta$-containing analytes were added to the cells to reach a final concentration of $1 \mu \mathrm{M} \mathrm{A} \beta$ peptide. The cells were then incubated for $24 \mathrm{~h}$ at $37^{\circ} \mathrm{C}$ with the analytes before measuring the cellular effects with one of two assays.

Cell metabolic activity was assessed with a FLUOstar Omega 96-well plate reader (BMG LABTECH) by using the Cell Proliferation Kit I (MTT, Roche) or LDHCytotoxicity Assay Kit II (BioVision) according to the manufacturer's protocol. Statistical analyses were carried out using the paired t-test implemented with SigmaPlot11 (Systat software).

\section{Results}

Oligomer and fibril targeting differentially affect $A \beta$ induced neurotoxicity in vivo

We transgenically expressed B10 or KW1 in Drosophila melanogaster flies within the central nervous system using

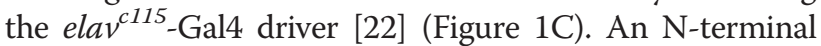
secretion signal peptide (SSP) ensures their insertion into the secretory pathway, whereas an additional C-terminal myc-tag was fused to aid their detection (Additional file 1: Figure S1). Reverse transcription polymerase chain reaction (Figure 1D,E) and anti-myc western blotting (Figure 1F,G) of fly head extracts from Drosophila expressing $\mathrm{B} 10$ or KW1 alone under the control of the elav ${ }^{c 155}$ Gal4 system confirmed that both proteins were stably expressed in KW1 and B10 flies. The two proteins relatively inert properties, as they do not discernibly affect the fly phenotype when expressed in isolation, as determined by locomotive behaviour (Figure $1 \mathrm{H}$ ), fly longevity (Figure 1I, Table 1) or eye structure (Figure 1J). Western blot shows only very little interactions between KW1 and B10 and endogenous fly proteins (Additional file 1: Figure S2). Expression of B10 and KW1 protein constructs in Drosophila Schneider S2 cells demonstrates that fly cells are able to express both antibody fragments as functional proteins that fully reproduce the conformational selectivity (Additional file 1: Figure S3) that we previously established for E.coli-derived proteins [29,30].

Flies were generated in which KW1 was co-expressed together with either of the peptides $A \beta(1-40), A \beta(1-42)$ or the early onset AD-associated E22G mutant $A \beta(1-$ 42)arc to investigate KW1's effects on $A \beta$ neurotoxicity. The resulting fly lines are termed KW1; $A \beta 40$, KW1; $A \beta 42$ and KW1; $A \beta 42$ arc. Whilst expression of $A \beta(1-40)$ or KW1 alone do not cause significant neurotoxicity in Drosophila (Figure 1H-J, Table 1), co-expression of A $\beta(1-40)$ with KW1 results in a significant $35 \%$ reduction in fly lifespan, compared to that of $A \beta(1-40)$ expressing flies (from $43 \pm 0.6$ days to $28 \pm 1.1$ days; Table 1). Analysis of the effects of KW1 expression in two other $A \beta(1-40)$ peptide-expressing lines $(A \beta(1-40)$ 29.1 and $A \beta(1-40)-51 D)$ shows that the magnitude of the increase in toxicity associated with KW1 co-expression in each case correlated with the concentration of $A \beta(1-40)$ (Figure 2D), as determined by western blot analysis of head homogenates (Additional file 1: Figure S4). Therefore, KW1 induces $A \beta(1-40)$-dependent neurotoxicity, although it does not discernibly affect other phenotypic properties, such as eye structure or climbing behaviour (Additional file 1: Figure S5A-C). The effect of KW1 is strikingly selective and co-expression with $A \beta(1-42)$ and $A \beta(1-42)$-arc does not cause any significant change in lifespan compared to the expression of $A \beta(1-42)$ or $\mathrm{A} \beta(1-42)$-arc alone (Additional file 1: Figure S5D-I).

While this selectivity fully agrees with in vitro data that KW1 preferentially interacts with $A \beta(1-40)$ oligomers (Figure 3), it sharply contrast to results obtained upon coexpression of B10 together with A $\beta$ in Drosophila, where we see no detectable phenotypic effects when compared to the expression of any of the $A \beta$ peptides alone (Additional file 1: Figure S5). For all examined properties we find $B 10 ; A \beta 40, B 10 ; A \beta 42$ and $B 10 ; A \beta 42$ arc flies to correspond to the respective lines $A \beta 40, A \beta 42$ and A $\beta 42$ arc. Although B10 is able to bind to all three fibril structures in vitro (Figure 3J) and although it perturbs fibril formation in vitro [30,35] and promotes protofibril formation at the expense of mature structures, fibril targeting with B10 does not affect the neurotoxicity of any of these peptides in vivo.

\section{KW1 selectively affects $A \beta(1-40)$ peptide and alters its deposition in the brain}

$A \beta 40$ flies do not exhibit significant $A \beta$ deposits by 20 days of age (Figure 4A,B), whereas co-expression of KW1 results in their appearance in age-matched flies (Figure 4B). KW1 partially co-localises with these foci and pull down of KW1 from KW1;A $\beta 40$ head homogenates results in the co-immunoprecipitation (co-IP) of $\mathrm{A} \beta(1-40)$ (Figure $4 \mathrm{C})$. While these data imply that KW1 affects the structure of $A \beta$ concomitantly with inducing its toxicity, interactions must be rather transient in nature as we see no complete co-localisation between the two expression products. KW1 expression also does not significantly increase the steady state levels of $A \beta(1-40)$ detected by western blotting of brain lysates of 3 or 

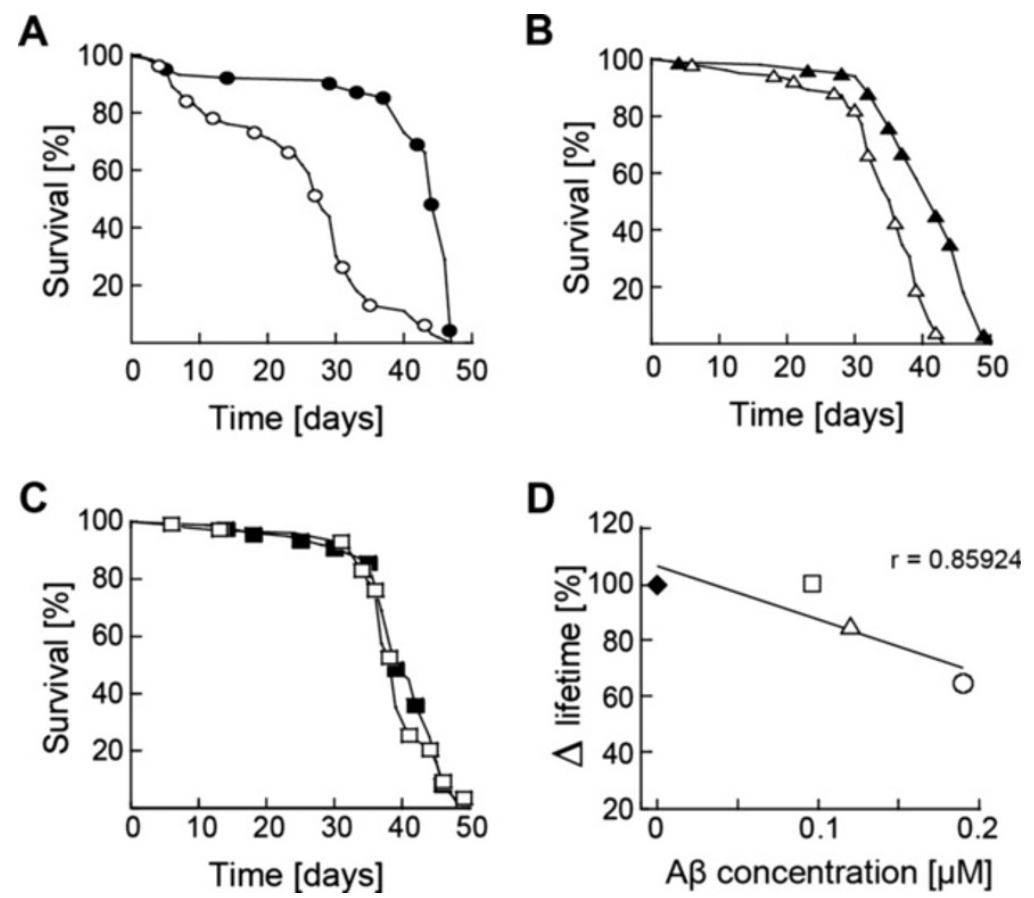

Figure $\mathbf{2}$ KW1 expression reduces the viability of different $A \beta(1-40)$ expressing fly lines. (A-C) Lifespan measurements of $A \beta 40$ flies (filled) and KW1;Aß40 flies (unfilled) (A), Aß40-51D flies (filled) and KW1;Aß40-51D flies (unfilled) (B) and Aß40-29.1 flies (filled) and KW1;Aß40-29.1 flies (unfilled) (C). (D) Fly viability versus $A \beta$ concentration in the fly head. The fly viability (\%) is given relative to fly lines without KW1 expression. Symbols: Filled diamond: KW1 relative to WT. Unfilled square: KW1;Aß40-29.1 relative to Ab40-29.1. Unfilled triangle: KW1;Aß40-51D relative to A 4 40-51D. Unfilled circle: KW1;A 440 relative to $A \beta 40$. Data were fitted by linear regression $(R=0.86)$. For original values please refer to Table 1 .

20 days-old KW1;A 340 flies (Figure 4D), and KW1 primarily alters the spatial distribution and/or assembly state of $A \beta(1-40)$ without dramatically changing its solubility.

Concerning B10, there was also no evidence that insufficient concentrations or a complete lack of interactions might explain the absence of effects of B10 expression on the flies. The ratio $\mathrm{B} 10$ to $\mathrm{A} \beta(1-42)$-arc present in the fly brain (1:3) (Additional file 1: Figure S6) exceeds that at which B10 has been shown to be effective at suppressing $A \beta$ fibril formation in vitro (as low as 1:10) [30]. Co-IP from fly head homogenates demonstrates that the two proteins are able to interact with one another (Additional file 1: Figure S4C), although there is only limited co-localization of the two expression products in B10;A 342arc flies (Additional file 1: Figure S4A, B).

\section{KW1 induces non-fibrillar aggregates with synaptotoxic activity}

The finding that KW1 expression specifically affects $A \beta(1$ 40)-transgenic animals was highly surprising, given that it had previously been shown to antagonize $A \beta(1-40)$ oligomer induced neurotoxicity (Figure $5 \mathrm{~A}, \mathrm{~B}$ ), as measured by the ability of preformed oligomers of $A \beta(1-40)$ to disrupt synaptic plasticity and LTP in cultured murine brain slices $[29,37,46]$. An obvious contrast between the fly model described here, and previous in vitro work is that KW1 is produced in the brain of the fly concomitantly with $\mathrm{A} \beta(1-40)$ peptide and is present during fibril or oligomer formation (Figure $5 \mathrm{C}$ ). Indeed, if we remodel such a situation in vitro by addition of KW1 to disaggregated $\mathrm{A} \beta(1-40)$ we find a significantly perturbed fibrillation pathway (Figure 5C). KW1 results in an extended lag phase and the formation of non-fibrillar species at the expense of mature fibrils (Figure 5D,E), similar to previous observations with dimeric KW1 [29]. Measured concentrations of KW1 $(\sim 1 \mu \mathrm{M})$ and $\mathrm{A} \beta(1-40)(\sim 0.2 \mu \mathrm{M})$ in fly head homogenates (Additional file 1: Figure S4) translate into a 5:1 molar stoichiometry and are significantly larger than the sub-stoichiometric 1:5 molar ratio of KW1 to $A \beta$, which suffices to perturb $A \beta(1-40)$ aggregation in vitro (Figure 5D,E).

The non-fibrillar aggregates formed by KW1 coincubation with disaggregated $A \beta(1-40)$ expose more surface hydrophobicity, as measured by increased binding of the dye 8-anilino-1-naphthalenesulfonic acid (ANS), than the more fibrillar aggregates formed in the absence of KW1 (Figure 5F). They also bind Thioflavin T (ThT), a dye that interacts with ordered $\beta$-sheet rich aggregates, more weakly than the more fibrillar species formed in the absence of KW1 (Figure 5G).

As surface exposed hydrophobics and weak ThT binding were previously described as a signature of toxic amyloid 


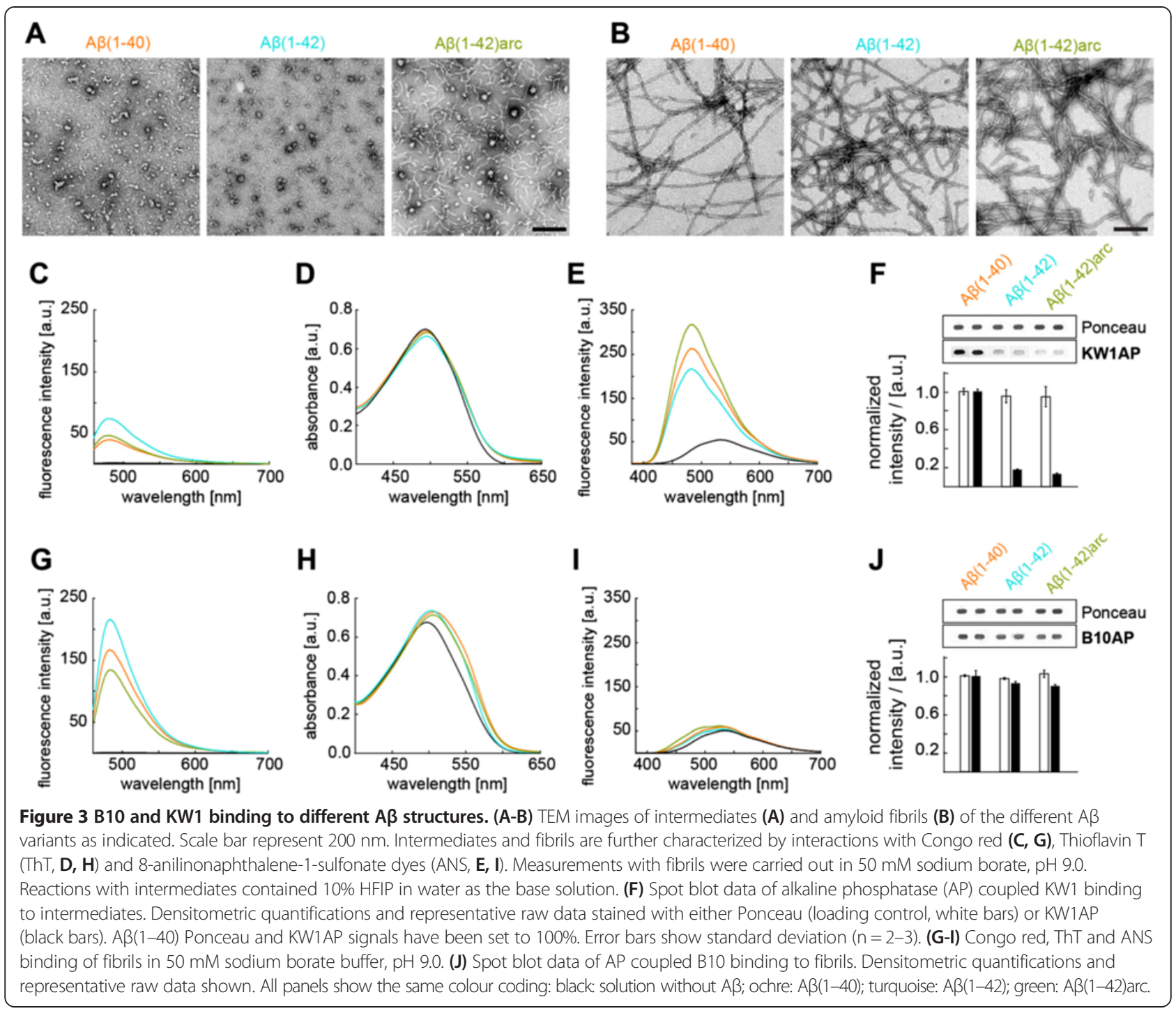

aggregates $[47,48]$, we sought to determine by LTP as to whether or not the neurotoxic effects of expressing KW1 with $A \beta(1-40)$ in vivo can be rationalised by the ability of KW1 to promote the formation of hydrophobic nonfibrillar $A \beta(1-40)$ aggregates. We applied different $\mathrm{A} \beta(1-40)$ preparations to the slice for 2 hours prior to electrophysiology recordings. We found that a 2 hour pre-incubation of the slices with 5-day old non-fibrillar $\mathrm{A} \beta(1-40)$ aggregates formed in the presence of $\mathrm{KW} 1$, prior to their addition to the culture, significantly inhibits LTP compared to untreated cultures (Figure $5 \mathrm{H}$ ). The synaptic potentiation measured at $225 \mathrm{~min}$ was $102 \% \pm 9$ field excitatory postsynaptic potential (fEPSP) with KW1-induced $A \beta(1-40)$ aggregates and $141 \% \pm 10$ fEPSP in the buffer treated control. No significant effect on the establishment of LTP is observed, if slices are pre-incubated for 2 hours with 5-day old A $\beta(1-40)$ fibrils formed in the absence of KW1 (Figure 5I) or if
KW1 was added to the fibrils after their formation but prior to their addition to the slice cultures (Figure 5J).

We confirmed these effects for a human neuronal system by adding these same $\mathrm{A} \beta(1-40) / \mathrm{KW} 1$ preparations to human neuroblastoma (SH-SY5Y) cells and measurement of their effects on neuronal metabolic activity with the 3-(4,5-dimethylthiazol-2-yl)-2,5-diphenyltetrazolium bromide (MTT) assay. Co-incubation of $\mathrm{A} \beta(1-40)$ with KW1 throughout the aggregation reaction generated aggregates that modulate the activity SH-SY5Y cells and induce a marked $\sim 12 \%$ reduction of the MTT value (Figure 6A), whereas those formed in the absence of KW1 or in the presence of B10 did not (Figure 6A). Notably, the activity of $A \beta(1-40)$ when co-incubated with KW1 increased with the length of the incubation time prior to their application to the cultured cells (from 1 to 5 days). This observation is in full accord with the effect of KW1 being to promote the progressive accumulation of 


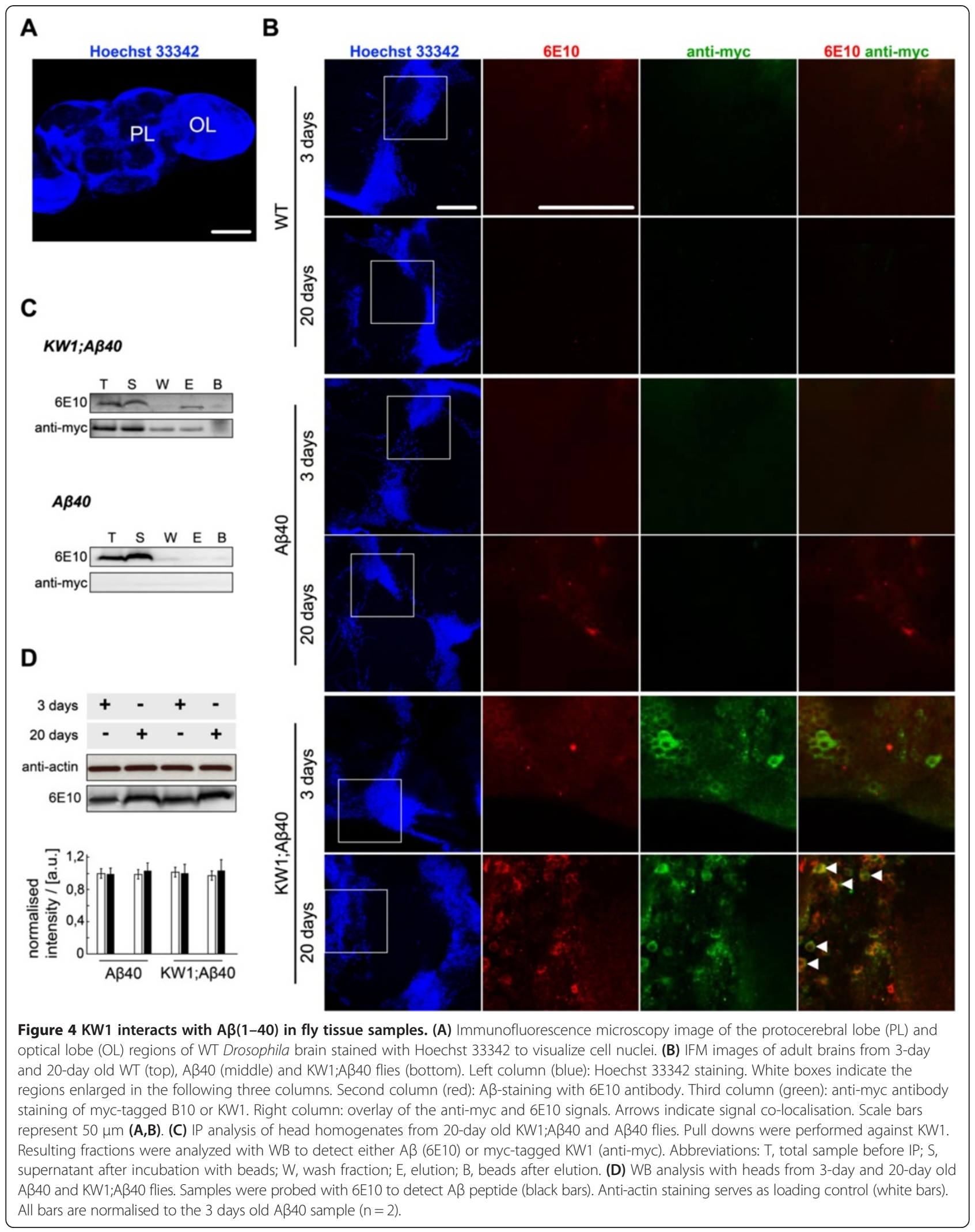




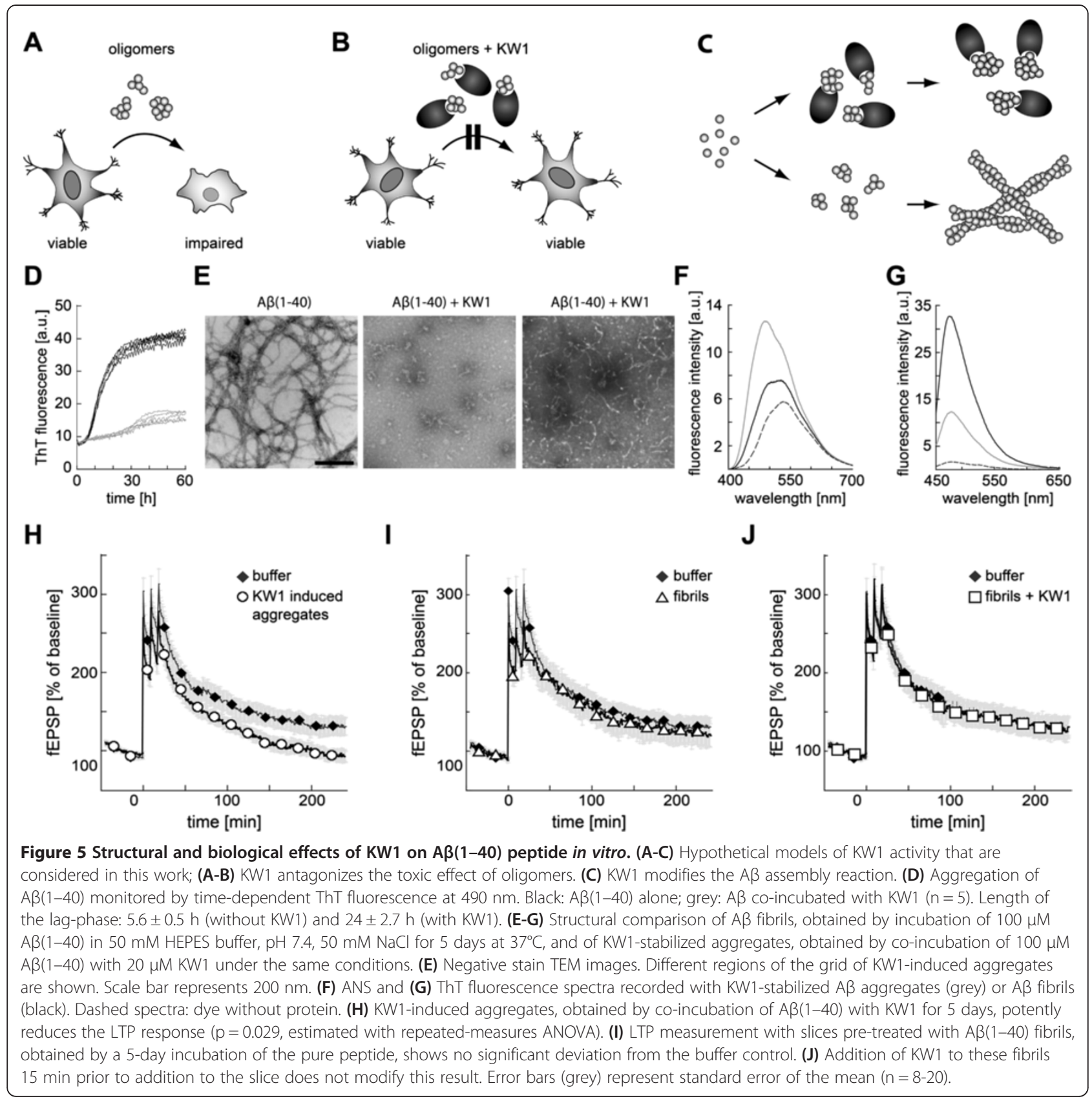

neurotoxic forms of $A \beta(1-40)$ aggregates over this time scale (Figure 6B). These effects of combinations of KW1 and $A \beta(1-40)$ on neuronal metabolic activity were significantly smaller than those observed following treatment with $A \beta(1-42)$ and $A \beta(1-42)$ arc peptides (Figure 6D). In line with other experimental paradigms reported here, the activities of the latter were also not modifiable by KW1 and did not depend on the presence or absence of this antibody fragment during aggregation.

While MTT does not directly monitor neuronal death in these experiments, lactate dehydrogenase (LDH) assay, which measures membrane disruption and thus reports more directly on cellular toxicity than MTT, shows no significant effects of $\mathrm{A} \beta$ on SH-SY5Y cells (Figure 6C), we find a striking correlation of the MTTeffects and fly toxicity in vivo (Figure 6E). Therefore, pure peptides are able to form species in vitro that capture activities associated with $\mathrm{A} \beta$ pathogenicity in vivo. They further testify to the existence of different populations of $A \beta$ assemblies inside the fly that differ in the chemical structure of $A \beta$ peptide, formation mechanism and sensitivity towards modulation by KW1; that is, there is no uniquely active $A \beta$ structure but a collection of toxic $A \beta$ structures in vitro and in vivo. 
A

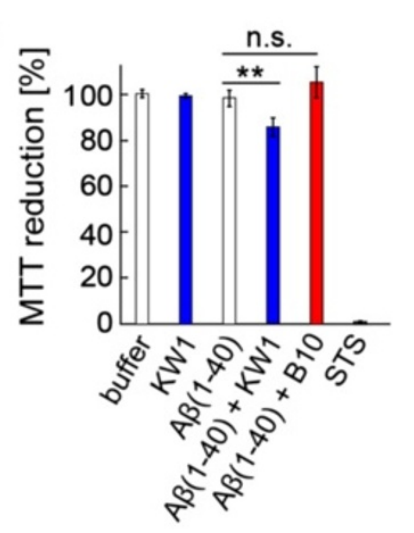

C

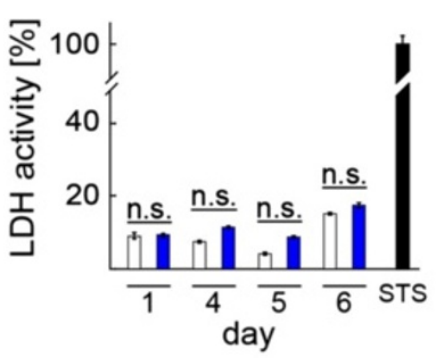

B

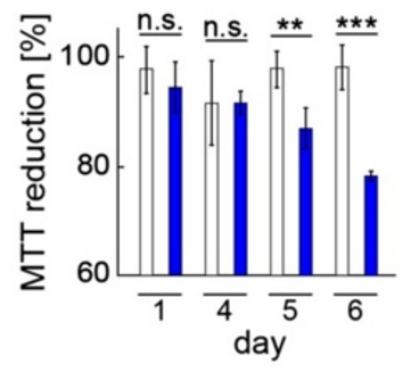

D

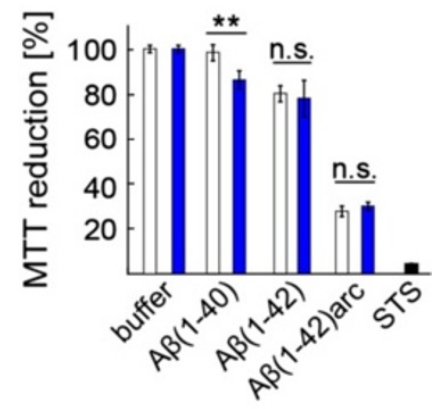

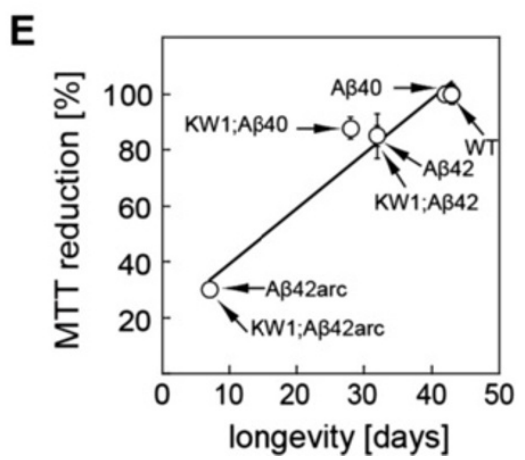

Figure 6 Effect of KW1 on the metabolic activity of A $\boldsymbol{\beta}$-species on SH-SY5Y cells. (A) MTT assay of SH-SY5Y cells treated with AB(1-40) aggregates after 5 days of incubation with or without antibody fragments at 5:1 molar ratio of A $\beta$ versus B10 or KW1. Molar ratio refers to the polypeptide chains. Cells treated with buffer were set to 100\%. The general cell toxin staurosporine (STS, $2 \mu M$ ) served as a positive control. $(\mathbf{B}, \mathbf{C})$ MTT-reduction (B) and LDH assay (C) of SH-SY5Y cells treated with A $(1-40)$ incubated for different periods of time with KW1 (blue) or without (white). SSP-treated cells defined 100\% LDH activity. (D) MTT assay of SH-SY5Y cells treated with A $\beta(1-40), A \beta(1-42)$ or $A \beta(1-42)$ arc peptides incubated in $50 \mathrm{mM} \mathrm{HEPES}$ buffer, $\mathrm{pH} 7.4,50 \mathrm{mM} \mathrm{NaCl}$ at $37^{\circ} \mathrm{C}$ for 5 days with KW1 (blue) or without (white). n.s.: non-significant, **: $p<0.01$, ***: $p<0.001$. Error bars represent standard deviation of $n=6$. (E) Corresponding $A \beta$ isoforms with or without KW1 plotted based on original life span data (Table 1) and MTT reduction in vitro (Figure 6). Please note the overlap of several data points. The strong correlation between MTT reduction and neurotoxicity in vivo fits with linear regression $(R=0.98)$.

\section{Discussion}

In this study we show that conformational targeting is a suitable approach to probe the process of $\mathrm{A} \beta$ aggregation and its neurotoxic consequences in an intact living organism, the fruit fly. Previous research already established that targeting of $\mathrm{A} \beta$ monomers in vivo with an artificial Affibody binding protein (analogous to the antibody fragments described here) is able to interfere with $\mathrm{A} \beta$ toxicity in vivo [49] and so we sought to extend this experimental design in the present study to investigate multimeric peptide assemblies of $A \beta$ in a similar manner. Our results reveal a striking contrast between the effects of targeting oligomeric and fibrillar assemblies of the $\mathrm{A} \beta$ peptide in vivo. Whilst the fibril-binding 
B10 antibody fragment is unable to perturb the neurotoxicity associated with any of the forms of $A \beta$ studied here, the oligomer-specific KW1 antibody fragment shows a potent and highly specific effect and alters toxicity in the fly model. This observation is consistent with the view that oligomeric intermediates are more toxic than mature fibrils.

Unexpectedly, KW1 promotes rather than neutralizes toxicity. This finding is in sharp contrast to many previous studies, which report oligomer-binding conformational ligands to antagonize the detrimental effects of oligomers (Figure $5 \mathrm{~A}, \mathrm{~B}$ ), presumably by preventing their binding to cellular surfaces or receptors. These previous studies usually used an experimental set up where the disturbance of ordered neuronal functions was recorded in response to preformed toxic oligomers. Thus, addition of an oligomerspecific binder to this system interfered with this process and blocked the effects of oligomers on neurons [50-56]. If KW1 is explored under such a set-up, for example by using LTP measurements as the readout of toxicity, we find oligomeric activity to be blocked [29], similar to many other oligomer-specific ligands.

This test system, however, does not capture the possibility that an oligomer-binder can affect the peptide during aggregates, which is physiologically relevant as KW1 is present in the fly together with $A \beta(1-40)$ peptide for prolonged periods of time. If we remodel this situation in vitro by allowing $A \beta(1-40)$ peptide to aggregate in the presence of KW1, we obtain a result that is now fully consistent with the fly data and demonstrates an increased $A \beta$ activity in both LTP (Figure $5 \mathrm{H}$ ) and MTT assays (Figure 6A). The mechanism underlying these effects appears therefore to involve interference by the oligomer-specific binder KW1 with the process of the assembly of $\mathrm{A} \beta$ peptides into amyloid structures (Figure 5C). This effect could result from a variety of processes, such as the suppression of the late stages of the aggregation reaction through binding to early intermediates or interaction with late-stage intermediates such that non-fibrillar $A \beta$ assemblies prevail (Figure $5 \mathrm{E}$ ). Indeed, the effects of KW1 are also associated with an altered structure of the $A \beta$ peptide that is evident from TEM (Figure 5E) and ANS binding experiments (Figure 5F). Moreover, it appears that the $A \beta(1-40)$ peptide only becomes toxic under certain conditions, such as is observed here in the presence of KW1 as a cofactor.

Another highly remarkable finding from our fly studies is that KW1 selectively affected $A \beta(1-40)$-expressing flies and mirrors the in vitro observation that KW1 preferentially interacts with $A \beta(1-40)$-derived oligomers compared with $A \beta(1-42)$ or $A \beta(1-42)$-arc-derived intermediates (Additional file 1: Figure S5A, D, G). That is, there must be at least subtle differences in the structure or surface texture of these states and also, as $A \beta$ toxicity is not affected by KW1 in all fly models, in the mechanisms by which they form.

These data have significance for the design of $A \beta$ modifying therapeutic strategies for the treatment of Alzheimer's disease. First, if $\mathrm{A} \beta$-dependent $\mathrm{AD}$ pathology does not only depend on a single $A \beta$ state, strategies to bind and to neutralize $A \beta$ peptide more generally or to simultaneously prevent formation of multiple peptide assembly states may be preferable for achieving efficient therapeutic design rather than targeting a single, though highly toxic, molecular state. Second, the biological activity of statespecific binders might be highly context-dependent, as may not only block the binding of oligomers to their cellular receptors, but also modulate the peptide self-assembly reaction. Therefore, the biological consequences of a binder are difficult to predict a priori, and the same protein, KW1, can either prevent or enhance the neurotoxicity of $A \beta(1-40)$ depending on the time point in the aggregation process at which it is added. We believe that this effect could be in particular a problem of approaches that solely aim to target oligomers in order to antagonize their activity by binding. In the case of proteins with additional activities, such as full-blown antibodies with functional Fc-parts, however, these effects could be overruled as they may alert the immune system to induce the specific destruction of the bound ligand. This explains why oligomer-specific antibodies may be functional in vivo $[53,55]$.

\section{Conclusions}

Understanding the kinetics and underlying mechanisms of $A \beta$ aggregation in the brains or patients suffering from $A D$, and the balance of these process with those that facilitate degradation and clearance of aggregates, is crucial for maximising the efficacy of therapeutic strategies based on the modulation of $A \beta$ aggregation. Conformational targeting with appropriately designed antibody fragments is not only a way to determine the types of aggregates that are present in the intact nervous system of a living animal, but also to analyse the functional effects arising from specific perturbations of the mechanisms of $\mathrm{A} \beta$ peptide aggregation in vivo. By combining these studies with in vitro analysis of the biophysical properties of the antibody fragments and their interactions with $A \beta$, it is possible to provide significant insights into the molecular basis of the pathogenesis of conformational diseases and perhaps to generate successful strategies, or to detect potential pitfalls, when devising therapeutic solutions to these devastating diseases.

\section{Additional file}

Additional file 1: Figure S1. Amino acid sequences of the expressed polypeptide chains. Figure S2. B10AP and KW1AP do not cross-react with Drosophila proteins. Figure S3. Drosophila Schneider S2 cells are 
able to express functional KW1 and B10 antibody fragments. Figure S4. Phenotypic effects of KW1 and B10 expression on A $A$-transgenic flies.

Figure S5. B10 interacts with $A \beta$ peptide in tissue samples. Figure S6. Concentrations of $A \beta, B 10$ and KW1 in fly head homogenates.

\section{Competing interests}

All authors declare that there are no competing interests.

\section{Authors' contributions}

$J W, R R, M W, M W$ and $L M L$ carried out research, KGR, CMD, UH, DCC, LML and MF designed research, JW, MW, LML. and MF wrote the paper. All authors read and approved the final manuscript.

\section{Acknowledgements}

MF was supported by Bundesministerium für Bildung und Forschung (BioFuture), Deutsche Forschungsgemeinschaft (Sonderforschungsbereich 610), Alzheimer Forschung Initiative (AFI) e.V. and the country SachsenAnhalt (Exzellenznetzwerk Biowissenschaften). LML and CMD are supported by grants from the Wellcome Trust and Medical Research Council. DCC was supported by an Alzheimer's Research UK Senior Research Fellowship (grant code: ART-SRF2010-2) and is supported by the Wellcome Trust and Medical Research Council (grant code: 082604/2/07/Z).

\section{Author details}

${ }^{1}$ Max-Planck Research Unit for Enzymology of Protein Folding, 06120 Halle, Saale, Germany. ${ }^{2}$ German Centre for Neurodegenerative Diseases (DZNE), 39118 Magdeburg, Germany. ${ }^{3}$ Electron Microscopy Center, Jena University Hospital, Friedrich Schiller University Jena, 07743 Jena, Germany. ${ }^{4}$ Institute for Pharmaceutical Biotechnology, Ulm University, Helmholtzstr.

8/1, 89081 Ulm, Germany. ${ }^{5}$ Department of Chemistry, University of Cambridge, Cambridge CB2 1EW, UK. 'eibniz Institut für Naturstoff-Forschung und Infektionsbiologie, Hans-Knöll-Institut, 07745 Jena, Germany. ${ }^{7}$ Department of Genetics, University of Cambridge, Cambridge CB2 3EH, UK. ${ }^{8}$ Cambridge Institute for Medical Research, Cambridge CB2 OXY, UK. ${ }^{9}$ Present address: MVZ Labor Dessau GmbH, Bauhüttenstr. 6, 06847 Dessau, Germany.

\section{Received: 4 February 2014 Accepted: 3 April 2014}

\section{Published: 11 April 2014}

\section{References}

1. Eisenberg D, Jucker M (2012) The amyloid state of proteins in human diseases. Cell 148:1188-1203

2. Bellotti V, Mangione P, Merlini G (2003) Molecular mechanisms of amyloidosis. N Engl J Med 349:583-596

3. Chiti F, Dobson CM (2006) Protein misfolding, functional amyloid, and human disease. Annu Rev Biochem 75:333-366

4. Eichner T, Radford SE (2011) A diversity of assembly mechanisms of a generic amyloid fold. Mol Cell 43:8-18

5. Dodel RC, Hampel H, Du YS (2003) Immunotherapy for Alzheimer's disease. Lancet Neurol 2:215-220

6. Haass C, Selkoe DJ (2007) Soluble protein oligomers in neurodegeneration: lessons from the Alzheimer's amyloid bold beta-peptide. Nat Rev Mol Cell Biol 8:101-112

7. Ittner LM, Götz J (2011) Amyloid- $\beta$ and tau-a toxic pas de deux in Alzheimer's disease. Nat Rev Neurosci 12:65-72

8. Walsh DM, Teplow DB (2012) Alzheimer's disease and the amyloid $\beta$ protein. Prog Mol Biol Tranls 107:101-124

9. Morgado I, Fändrich M (2011) Review: assembly of Alzheimer's A $\beta$ peptide into nanostructured amyloid fibrils. Curr Opin Colloid In 16:508-514

10. Nilsberth C, Westlind-Danielsson A, Eckman CB, Condron MM, Axelman $K$, Forsell C, Stenh C, Luthman J, Teplow DB, Younkin SG, Näslund J, Lannfelt L (2001) The 'Arctic' APP mutation (E693G) causes Alzheimer's disease by enhanced Abeta protofibril formation. Nat Neurosci 4:887-893

11. Schilling S, Zeitschel U, Hoffmann T, Heiser U, Francke M, Kehlen A, Holzer M, Birgit Hutter-Paier B, Prokesch M, Windisch M, Jagla W, Schlenzig D, Lindner C, Rudolph T, Reuter G, Cynis H, Montag D, Demuth HU, Rossner S (2008) Glutaminyl cyclase inhibition attenuates pyroglutamate Abold beta and Alzheimer's disease-like pathology. Nat Med 14:1106-1111
12. Lashuel HA, Lansbury PT Jr (2006) Are amyloid diseases caused by protein aggregates that mimic bacterial pore-forming toxins? Q Rev Biophys 39:167-201

13. Cherny I, Gazit E (2008) Amyloids: not only pathological agents but also ordered nanomaterials. Angew Chem Int Edit 47:4062-4069

14. Fändrich M (2012) Oligomeric intermediates in amyloid formation: structure determination and mechanisms of toxicity. J Mol Biol 421:427-440

15. Lesne S, Koh MT, Kotilinek L, Kayed R, Glabe CG, Yang A, Gallagher M, Ashe $\mathrm{KH}$ (2005) A specific amyloid- $\beta$ protein assembly in the brain impairs memory. Nature 440:352-357

16. Martins IC, Kuperstein I, Wilkinson H, Maes E, Vanbrabant M (2008) Lipids revert inert Abeta amyloid fibrils to neurotoxic protofibrils that affect learning in mice. EMBO J 27:224-233

17. Glabe CG (2004) Conformation-dependent antibodies target diseases of protein misfolding. Trends Biochem Sci 29:542-547

18. O'Nuallain B, Ronald Wetzel R (2002) Conformational Abs recognizing a generic amyloid fibril epitope. Proc Natl Acad Sci U S A 99:1485-1490

19. Perchiacca JM, Ladiwala AR, Bhattacharya M, Tessier PM (2012) Structurebased design of conformation- and sequence-specific antibodies against amyloid $\beta$. Proc Natl Acad Sci U S A 109:84-89

20. Nerelius C, Sandegren A, Sargsyan H, Raunak R, Leijonmarck H, Chatterjee U, Fisahn A, Imarisio S, Lomas DA, Crowther DC, Strömberg R, Johansson J (2009) Alpha-helix targeting reduces amyloid-beta peptide toxicity. Proc Natl Acad Sci U S A 106:9191-9196

21. Kvam E, Nannenga BL, Wang MS, Jia Z, Sierks MR, Messer A (2009) Conformational targeting of fibrillar polyglutamine proteins in live cells escalates aggregation and cytotoxicity. PLoS ONE 4(5):e5727, doi:10.1371/ journal.pone.0005727

22. Crowther DC, Kinghorn KJ, Miranda E, Page R, Curry JA, Duthie FA, Gubb DC, Lomas DA (2005) Intraneuronal Abeta, non-amyloid aggregates and neurodegeneration in a Drosophila model of Alzheimer's disease. Neuroscience 132:123-135

23. Luheshi LM, Tartaglia GG, Brorsson AC, Pawar AP, Watson IE, Chiti F, Vendruscolo M, Lomas DA, Dobson CM, Crowther DC (2007) Systematic in vivo analysis of the intrinsic determinants of amyloid Beta pathogenicity. PLoS Biol 5(11):e290, doi:10.1371/journal.pbio.0050290

24. Rival T, Page RM, Chandraratna DS, Sendall TJ, Ryder E, Liu B, Lewis H, Rosahl T, Hider R, Camargo LM, Shearman MS, Crowther DC, Lomas DA (2009) Fenton chemistry and oxidative stress mediate the toxicity of the beta-amyloid peptide in a Drosophila model of Alzheimer's disease. Eur J Neurosci 29:1335-1347

25. Liu B, Moloney A, Meehan S, Morris K, Thomas SE, Serpell LC, Hider R, Marciniak SJ, Lomas DA, Crowther DC (2011) Iron promotes the toxicity of amyloid beta peptide by impeding its ordered aggregation. J Biol Chem 286:4248-4256

26. Sofola O, Kerr F, Rogersl KK, Augustin H, Gandy C, Allen MJ, Hardy J, Lovestone S, Partridge L (2010) Inhibition of GSK-3 ameliorates A $\beta$ pathology in an adult-onset Drosophila model of Alzheimer's disease. PLoS Genet 6(9):e1001087, doi:10.1371/journal.pgen.1001087

27. Auluck PK, Caraveo G, Lindquist S (2010) a-Synuclein: membrane interactions and toxicity in Parkinson's disease. Annu Rev Cell Dev Biol 26:211-233

28. Wittmann CW, Wszolek MF, Shulman JM, Salvaterra PM, Lewis J, Hutton M, Feany MB (2001) Tauopathy in Drosophila: neurodegeneration without neurofibrillary tangles. Science 293:711-714

29. Morgado I, Wieligmann K, Bereza M, Rönicke R, Meinhardt K, Annamalai K, Baumann M, Wacker J, Hortschansky P, Malešević M, Parthier C, Mawrin C, Schiene-Fischer C, Reymann KG, Stubbs MT, Balbach J, Görlach M, Horn U, Fändrich M (2012) Molecular basis of $\beta$-amyloid oligomer recognition with a conformational antibody fragment. Proc Natl Acad Sci U S A 109:12503-12508

30. Habicht G, Haupt C, Friedrich RP, Hortschansky P, Sachse C, Meinhardt J, Wieligmann K, Gellermann GP, Brodhun M, Götz J, Halbhuber KJ, Röcken C, Horn U, Fändrich M (2007) Directed selection of a conformational antibody domain that prevents mature amyloid fibril formation by stabilizing $A \beta$ protofibrils. Proc Natl Acad Sci U S A 104:19232-19237

31. Haupt C, Morgado I, Kumar ST, Parthier C, Bereza M, Hortschansky P, Stubbs MT, Horn U, Fändrich M (2011) Amyloid fibril recognition with the conformational B10 antibody fragment depends on electrostatic interactions. J Mol Biol 405:341-348

32. Haupt C, Bereza M, Kumar ST, Kieninger B, Morgado I, Hortschansky P, Fritz G Röcken C, Horn U, Fändrich M (2011) Pattern recognition with a fibril-specific antibody fragment reveals the surface variability of natural amyloid fibrils. J Mol Biol 408:529-540 
33. Upadhaya AR, Lungrin I, Yamaguchi H, Fändrich M, Thal DR (2012) Highmolecular weight $A \beta$ oligomers and protofibrils are the predominant $A \beta$ species in the native soluble protein fraction of the AD brain. J Cell Mol Med 16:287-295

34. Kieninger B, Gioeva Z, Krüger S, Westermark GT, Friedrich RP, Fändrich M, Röcken C (2011) PTAA and B10: new approaches to amyloid detection in tissue-evaluation of amyloid detection in tissue with a conjugated polyelectrolyte and a fibril-specific antibody fragment. Amyloid 18:47-52

35. Scheidt HA, Morgado I, Rothemund S, Huster D, Fändrich M (2011) Solidstate NMR spectroscopic investigation of $A \beta$ protofibrils: implication of a $\beta$-sheet remodeling upon maturation into terminal amyloid fibrils. Angew Chem Int Ed Engl 50:2837-2840

36. Hortschansky P, Schroeckh V, Christopeit T, Zandomeneghi G, Fändrich M (2005) The aggregation kinetics of Alzheimer's $\beta$-amyloid peptide is controlled by stochastic nucleation. Prot Sci 14:1753-1759

37. Haupt C, Leppert J, Rönicke R, Meinhardt J, Yadav JK, Ramachandran R, Ohlenschläger O, Reymann KG, Görlach M, Fändrich M (2012) Structural basis of $\beta$-amyloid-dependent synaptic dysfunctions. Angew Chem Int Ed 7:1576-1577

38. Bischof K (2007) An optimized transgenesis system for Drosophila using germ-line-specific $\varphi$ C31 integrases. Proc Natl Acad Sci U S A 104:3312-3317

39. Green C, Levashina E, McKimmie C, Dafforn T, Reichhart JM, Gubb D (2000) The necrotic gene in Drosophila corresponds to one of a cluster of three serpin transcripts mapping at 43A1.2. Genetics 156:1117-1127

40. Brand AH, Perrimon N (1993) Targeted gene expression as a means of altering cell fates and generating dominant phenotypes. Development 118:401-415

41. Speretta E, Jahn TR, Tartaglia GG, Favrin G, Barros TP, Imarisio S, Lomas DA, Luheshi LM, Crowther DC, Dobson CM (2012) Expression in drosophila of tandem amyloid beta peptides provides insights into links between aggregation and neurotoxicity. J Biol Chem 287:20748-20754

42. Ashburner M, Golic KG, Hawley RS (2005) Drosophila: a laboratory handbook, 2nd edn. Cold Spring Harbor Laborators Press, Cold Spring Harbor, New York, XXVIII 1408pp

43. Christopeit T, Hortschansky P, Schroeckh V, Gührs K, Zandomeneghi G, Fändrich M (2005) Mutagenic analysis of the nucleation propensity of oxidized Alzheimer's $\beta$-amyloid peptide. Protein Sci 14:2125-2131

44. Gill SC, von Hippel PH (1989) Calculation of protein extinction coefficients from amino acid sequence data. Anal Biochem 182:319-326

45. Rönicke R, Mikhaylova M, Rönicke S, Meinhardt J, Schröder UH, Fändrich M Reiser G, Kreutz MR, Reymann KG (2011) Early neuronal dysfunction by amyloid $\beta$ oligomers depends on activation of NR2B-containing NMDA receptors. Neurobiol Aging 32:2219-2228

46. Rönicke R, Klemm A, Meinhardt J, Schröder UH, Fändrich M, Reymann KG (2008) Abeta mediated diminution of MTT reduction-an artefact of single cell culture? PLOS ONE 3(9):e3236, doi:10.1371/journal.pone.0003236

47. Bolognesi B, Kumita JR, Barros TP, Esbjorner EK, Luheshi LM, Crowther DC, Wilson MR, Dobson CM, Favrin G, Yerbury JJ (2010) ANS binding reveals common features of cytotoxic amyloid species. ACS Chem Biol 5:735-740

48. Krishnan R, Goodman JL, Mukhopadhyay S, Pacheco CD, Lemke EA, Deniz AA, Lindquist $S$ (2012) Conserved features of intermediates in amyloid assembly determine their benign or toxic states. Proc Natl Acad Sci U S A 109:11172-11177

49. Luheshi LM, Hoyer W, Pereira de Barros T, van Dijk HI, Brorsson AC, Macao B, Persson C, Crowther DC, Lomas DA, Stahl S, Dobson CM, Härd T (2010) Sequestration of the Abeta peptide prevents toxicity and promotes degradation in vivo. PLoS Biol 8(3):e1000334, doi:10.1371/journal. pbio.1000334

50. Wang $X P$, Zhang JH, Wang $Y J$, Feng $Y$, Zhang $X$, Sun $X X$, Li JL, Du XT, Lambert MP, Yang SG, Zhao M, Klein WL, Liu RT (2009) Conformationdependent single-chain variable fragment antibodies specifically recognize beta-amyloid oligomers. FEBS Lett 583:579-584

51. Lambert MP, Viola KL, Chromy BA, Chang L, Morgan TE, Yu J, Venton DL, Krafft GA, Finch CE, Klein WL (2001) Vaccination with soluble A $\beta$ oligomers generates toxicity-neutralizing antibodies. J Neurochem 79:595-605

52. Kayed R, Head E, Thompson JL, McIntire TM, Milton SC, Cotman CW, Glabe CG (2003) Common structure of soluble amyloid oligomers implies common mechanism of pathogenesis. Science 300:486-489

53. Lee EB, Leng LZ, Zhang B, Kwong L, Trojanowski JQ, Abel T, Lee VM (2006) Targeting amyloid-beta peptide (Abeta) oligomers by passive immunization with a conformation-selective monoclonal antibody improves learning and memory in Abeta precursor protein (APP) transgenic mice. J Biol Chem 281:4292-4299

54. Goñi F, Prelli F, Ji Y, Scholtzova H, Yang J, Sun Y, Liang FX, Kascsak R, Kascsak R, Mehta P, Wisniewski T (2010) Immunomodulation targeting abnormal protein conformation reduces pathology in a mouse model of Alzheimer's disease. PLoS ONE 5(10):e13391, doi:10.1371/journal. pone.0013391

55. Hillen $H$, Barghorn S, Striebinger A, Labkovsky B, Müller R, Nimmrich $V$, Nolte MW, Perez-Cruz C, van der Auwera I, van Leuven F, van Gaalen M, Bespalov AY, Schoemaker H, Sullivan JP, Ebert U (2010) Generation and therapeutic efficacy of highly oligomer-specific beta-amyloid antibodies. J Neurosc 30:10369-10379

56. Shughrue PJ, Acton PJ, Breese RS, Zhao WQ, Chen-Dodson E, Hepler RW, Wolfe AL, Matthews M, Heidecker GJ, Joyce JG, Villarreal SA, Kinney GG (2010) Anti-ADDL antibodies differentially block oligomer binding to hippocampal neurons. Neurobiol Aging 31:189-202

doi:10.1186/2051-5960-2-43

Cite this article as: Wacker et al.: Oligomer-targeting with a conformational antibody fragment promotes toxicity in

A $\beta$-expressing flies. Acta Neuropathologica Communications 2014 2:43.

\section{Submit your next manuscript to BioMed Central and take full advantage of:}

- Convenient online submission

- Thorough peer review

- No space constraints or color figure charges

- Immediate publication on acceptance

- Inclusion in PubMed, CAS, Scopus and Google Scholar

- Research which is freely available for redistribution 